\title{
Złożoność organiczna jako nowe ujęcie złożoności systemów ekonomicznych
}

\section{Streszczenie}

Systemy ekonomiczne i społeczne należą do szerokiej klasy systemów złożonych stanowiących przedmiot zainteresowania licznych dziedzin nauki. Istnieje wiele ujęć złożoności takich systemów różniących się sposobem definiowania i objaśniania źródeł skomplikowanych zachowań. Ponieważ złożoność jest jednak zjawiskiem powszechnym i w przyrodzie, wydaje się uzasadnione poszukiwanie pewnego uniwersalnego wzorca powtarzalnego we wszystkich rodzajach systemów złożonych. W tym artykule przedstawiono nową koncepcję złożoności organicznej rozumianej jako zespół trzech atrybutów: asymetrii, mnogości i interaktywności elementów systemu. System posiadający te cechy będzie dysponować zdolnością wytwarzania złożonych struktur lub zachowań. Prezentowane podejście może być przydatne w tworzeniu modeli ekonomicznych i społecznych systemów złożonych.

Słowa kluczowe: systemy złożone, modele agentowe, symetria, samopodobieństwo.

\section{Wprowadzenie}

Organizacje i struktury społeczno-ekonomiczne należą do systemów, które można określić mianem złożonych. Rozpiętość skal, bogactwo zjawisk, różnorodność zachowań, nieprzewidywalność dynamiki, nieregularność procesów czy trudność w konstruowaniu matematycznych modeli to cechy charakteryzujące nie tylko systemy ekonomiczne, lecz również społeczeństwa ludzi, ekosystemy, sieci 
komputerowe, kolonie mrówek i wiele innych systemów stanowiących przedmiot badań licznych dziedzin nauki. Ubiegłe stulecie przyniosło zdecydowany wzrost zainteresowania złożonością wśród dyscyplin akademickich, który w ciągu ostatnich kilku dekad zaowocował powstaniem wielu koncepcji i teorii naukowych. Początkowo obszarem badań systemów złożonych była cybernetyka czy ogólna teoria systemów, a także teoria chaosu deterministycznego - a więc te gałęzie nauki, które w naturalny sposób zajmowały się informacją i dynamiką procesów. $\mathrm{Z}$ biegiem czasu pozwoliło to wykształcić nowe metody opisu i badania zjawisk złożonych, które przeniknęły do nauk przyrodniczych, społecznych czy ekonomicznych [Castellani i Hafferty 2009] i znalazły zastosowanie przy wyjaśnianiu wielu obserwowanych fenomenów zarówno w naturalnych, jak i stworzonych przez człowieka systemach.

Jednak obok badania konkretnych zjawisk złożonych interesującym polem eksploracji naukowej jest złożoność sama w sobie, potraktowana jako abstrakcyjna własność systemów dająca się analizować w oderwaniu od jej przejawów. Tak rozumiany przedmiot badań sprzyja formułowaniu teorii i koncepcji posiadających wysoki poziom ogólności, znajdujących później swoje odzwierciedlenie w bardzo odległych dyscyplinach opisujących pozornie zupełnie niezwiązane ze sobą zjawiska. Przykładem mogą posłużyć dziwne atraktory, samoorganizujące się stany krytyczne, bifurkacje i podwojenia okresu czy procesy perkolacji - pojęcia zaskakujące swoją uniwersalnością, spotykane w opisach różnych systemów biologicznych, elektronicznych, meteorologicznych, mechanicznych, chemicznych i wielu innych. Nie zawsze chronologia odkryć i prac nad tymi koncepcjami prowadzi od domeny abstrakcyjnej do konkretnych egzemplifikacji - bardziej naturalny jest raczej odwrotny scenariusz, w którym badacz najpierw obserwuje wybrane konkretne zjawisko, a dopiero później dokonuje uogólnienia dostrzeżonej prawidłowości.

Niemniej jednak uniwersalna, wszechobecna złożoność staje się również pociągającym przedmiotem prac badawczych prowadzonych od początku na płaszczyźnie abstrakcyjnej, których oś poznawcza prowadzi od ogólnych koncepcji do konkretnych zastosowań. Efektem połączenia obu kierunków jest nauka o złożoności - nieformalna jeszcze dyscyplina leżąca na pograniczu wielu dziedzin, która sama nie doczekała się do tej pory odrębnego i jednoznacznie określonego miejsca w strukturze współczesnej wiedzy, a zamiast tego pozostaje rozproszona wśród innych obszarów nauki [Waldrop 1992]. Szczególny wkład w rozwój wiedzy o złożoności wnosi technologia informatyczna, która, intensywnie rozwijając się zarówno pod względem ilościowym i jakościowym, dostarcza nowych narzędzi służących prowadzeniu eksperymentów symulacyjnych, budowaniu modeli obliczeniowych czy gromadzeniu i zautomatyzowanej analizie obszernych zbiorów danych opisujących skomplikowane zachowania systemów. 
W miarę rozwoju możliwości magazynowania, transmisji i przetwarzania informacji technika komputerowa dostarcza także nowych problemów badawczych, stwarzając nieznane dotąd środowiska i obiekty. Na przykład sieci komputerowe spajające miliony urządzeń w skali globalnej stają się niemalże całym ekosystemem, w którym zachodzi ewolucja oprogramowania, konkurencja o ograniczone zasoby czy optymalizacja dopasowania do środowiska. Cywilizacja ludzi, wykorzystując ową technologię, również wytwarza nieznane wcześniej systemy społeczno-ekonomiczne, buduje sieci relacji międzyludzkich, konstruuje wirtualne organizacje, produkuje niematerialne, cyfrowe dobra, wynajduje nowe formy handlu czy produkcji. Ta sama zatem technika, która pomaga w badaniu skomplikowanych i rozległych systemów, przyczynia się jednocześnie do dalszego wzrostu ich złożoności.

Podobnie więc, jak w wielu dziedzinach nauk przyrodniczych i technicznych, tak i w ekonomii i naukach o zarządzaniu rośnie zainteresowanie złożonością jako atrybutem systemów, jak również metodami jej eksperymentalnego wytwarzania, symulowania, kontrolowania czy prognozowania. Skłania to do poszukiwań pewnych uniwersalnych właściwości, których obecność z jednej strony powtarza się w różnorodnych systemach naturalnie występujących, z drugiej strony byłaby pożądana w sztucznie konstruowanych modelach. Odnalezienie takiego zestawu cech ma wartość nie tylko poznawczą, lecz również praktyczną, pozwala bowiem skierować uwagę badacza na istotne atrybuty decydujące o występowaniu przejawów złożoności w rzeczywistych systemach, ułatwiając ich odzwierciedlenie w konstrukcji modeli. W niniejszej pracy podjęto próbę wyłonienia takiego właśnie zestawu atrybutów, która prowadzi do sformułowania nowego ujęcia złożoności, nazwanego złożonością organiczną.

\section{Różne ujęcia złożoności}

Zachowania złożone można obserwować w systemach należących do obszaru każdej niemal dziedziny nauk. Jako jeden z najwcześniejszych przykładów usystematyzowanych badań złożoności w nowożytnej nauce można przytoczyć rozważane przez H. Poincare problemy natury astronomicznej, dotyczące ruchu układu mas w ich własnych polach grawitacyjnych [Diacu 1996]. Z kolei późniejsze badania nad chaosem deterministycznym zapoczątkowane przez E. Lorenza [1963] obejmowały pierwotnie zjawiska meteorologiczne, związane z przepływem mas powietrza w atmosferze. Sięgając po przykład z innej dziedziny, można wymienić badania struktur dyssypatywnych, które na gruncie chemii prowadził I. Prigogine [1961]. Pojęcie złożoności nie ogranicza się jednak tylko do nauk przyrodniczych 
i pojawia się coraz częściej w pracach z zakresu ekonomii, zarządzania, socjologii, ekologii, biologii i wielu innych obszarów.

Biorąc pod uwagę różnorodność zjawisk i systemów można spodziewać się rozmaitych podejść w badaniach złożoności, którą interpretuje się i opisuje na wiele sposobów, upatrując zasadniczych atrybutów złożoności w odmiennych cechach struktury i dynamiki systemów. Dla przedstawiciela nauk o zarządzaniu istotne będą na przykład takie właściwości, jak zdolność do adaptacji i uczenia się jednostek i całych organizacji, umiejętność komunikowania się oraz kooperacji, które sprawiają, że zbiorowości zachowują się w bardziej skomplikowany sposób niż ich części, przy czym może to dotyczyć nie tylko ludzkich organizacji, ale także zbiorowości agentów informatycznych. Dla inżyniera badającego układy o dynamice chaotycznej istotne znaczenie będzie miała silna wrażliwość na warunki początkowe, trajektoria systemu w przestrzeni stanów, obecność atraktorów czy gwałtowne przejścia między regularnymi i nieregularnymi zachowaniami. Informatyk zwróci uwagę na wymagania obliczeniowe i pamięciowe implementowanych algorytmów, postrzegając zazwyczaj złożoność jako ilościową, niepożądaną cechę procesów obliczeniowych. W przeciwieństwie do tego specjalista kryptografii będzie interpretował złożoność jako zaletę metod utajniania informacji decydującą o ich bezpieczeństwie i odporności na próby ataków. Ujęcia złożoności mogą być więc w zależności od dyscypliny zarówno bardzo ogólne, jak i niezwykle wąsko wyspecjalizowane.

Wraz z rosnącym wykorzystaniem metod obliczeniowych i podejść agentowych w tworzeniu modeli i badaniu zachowania się systemów w naukach ekonomicznych pojęcie złożoności odgrywa coraz większą rolę. W zależności od sposobu opisu zjawisk i przyjętego programu badawczego spotyka się różne określenia złożoności. Na przykład za zjawiska złożone można uznać takie, do których analizy konieczne jest użycie zbiorów cech i nawet po ich wyselekcjonowaniu metodami statystycznymi nie udaje się ograniczyć opisu zjawiska do pojedynczej zmiennej [Pawełek 2008]. Inne ujęcia kładą nacisk na niestabilność systemów spowodowaną nieustannymi zmianami zachodzącymi w tworzących je populacjach, co dla modeli prognostycznych stanowi duże wyzwanie, czyniąc przewidywania oparte na danych pochodzących z obserwacji systemu znajdującego się w jednej fazie dynamiki, na przykład wzroście gospodarczym, nieadekwatnymi do sytuacji w innej fazie, na przykład recesji [Pociecha i Pawełek 2010]. Inni badacze kierują się ku aspektom sieciowym, dynamicznym, agentowym, ewolucyjnym czy adaptacyjnym, by wymienić tylko kilka przykładów z szerokiego spektrum podejść badawczych do problemu złożoności w naukach ekonomicznych [Modeling Complexity... 2002]. Część z tych podejść koncentruje się na obecności powiązanych sprzężeniami zwrotnymi licznych agentów, dokonujących wyborów na podstawie swoich oczekiwań co do analogicznych wyborów podejmowanych 
przez resztę populacji. Wzajemne wykluczanie się trafności prognozy przewidującej, jak postąpią inni, oraz możliwości zdecydowania na jej podstawie, jak postąpić samemu [Challet i Zhang 1997], wytrąca system z równowagi i trwale uniemożliwia jej osiągnięcie, nadając mu w ten sposób złożony, nieustannie zmienny charakter [Arthur 1999]. Odmienna perspektywa zwraca uwagę na własności systemów złożonych związane z występowaniem w nich samoorganizujących się stanów krytycznych. W systemach tego rodzaju drobne bodźce o lokalnym charakterze kumulują się, by wyzwolić niekiedy burzliwe globalne efekty o charakterze przejść fazowych [Scheinkman i Woodford 1994].

Dokonując próby systematyzacji rodzajów złożoności w systemach społeczno-ekonomicznych i przyjmując sposób manifestowania się złożoności jako podstawę typologii, można wyróżnić cztery zasadnicze kategorie [Mesjasz 2010]: złożoność rekursywną, poznawczą, chaotyczną i obliczeniową. Złożoność rekursywna wynika albo z konstrukcji logicznej odnoszącej się do samej siebie - tak jak w przypadku rozstrzygania problemów za pomocą tego samego systemu formalnego, w którym są osadzone, albo z obecności wewnętrznych zwrotnych relacji między opisywanym systemem i obserwującymi go podmiotami. Złożoność poznawcza jest konsekwencją podstawowego związku obserwatora i przedmiotu badań egzystujących w tej samej rzeczywistości, w której umysł i świadomość badacza zakłóca jego percepcję, a nieokreśloność i subiektywizm znaczeń nadawanych obserwacjom utrudnia zrozumienie i komunikację pomiędzy podmiotami. Złożoność chaotyczna jest właściwością nieliniowych systemów dynamicznych o nieregularnym zachowaniu, silnie wrażliwych na zmiany warunków początkowych, które utrudniają lub wręcz uniemożliwiają przewidywanie stanów przyszłych, co wiąże tę kategorię ze złożonością poznawczą. Złożoność obliczeniowa wiąże się z problemami o zróżnicowanej trudności, jaką sprawiają przy rozwiązywaniu ich metodami algorytmicznymi. Ta kategoria obejmuje wiele problemów, od zadań wykonywalnych w dającym się akceptować czasie, poprzez problemy rozwiązywalne jedynie w sposób przybliżony, aż do kwestii całkowicie nierozstrzygalnych w drodze obliczeniowej [Arora i Barak 2009]. W rzeczywistych systemach, na które składają się inteligentni i świadomi ludzie, powyższe charakterystyki występują jednocześnie, co skłania do określenia systemów społecznych mianem „złożonych złożoności” [Mesjasz 2009].

\section{Powszechność złożoności}

Pomimo tak wielu zróżnicowanych sposobów opisu i badania złożoności wynikających z odmiennych perspektyw postrzegania przedmiotu badań przez odmienne, odległe niekiedy dyscypliny nauki, sama złożoność wydaje się atry- 
butem bardzo uniwersalnym i powszechnym. Różni badacze reprezentujący poszczególne obszary wiedzy naukowej mogą analizować to samo zjawisko, stosując za każdym razem odmienne systemy pojęć i metody pracy. Zjawiska zachodzące w systemach społeczno-ekonomicznych są dobrym tego przykładem, gdyż można opisywać je, używając koncepcji statystycznych, informatycznych, cybernetycznych, socjologicznych, fizycznych czy biologicznych, za każdym razem definiując złożoność w inny, specyficzny dla danego podejścia sposób. Nie oznacza to jednak, że złożoność tych systemów jest wewnętrznie zróżnicowana, wywodzi się z odrębnych źródeł czy wymaga innych warunków, by mogła się ujawnić. Przytoczone powyżej ujęcia i klasyfikacje dotyczą raczej różnych przejawów i konsekwencji złożoności, nie poszukując przy tym pewnego wspólnego wzorca leżącego u podłoża wszystkich tych odmian złożoności.

Postęp wiedzy o złożoności i rozwój metod jej poznawania skłania jednak do wyciągnięcia wniosku, że poszczególne jej warianty i manifestacje powinny posiadać uniwersalne podłoże. Przemawia za tym nie tylko estetyczne kryterium elegancji zunifikowanych teorii w nauce, ale przede wszystkim to, że osiągnięcia jednej dyscypliny zajmującej się określoną klasą systemów można adaptować do badania systemów tradycyjnie zarezerwowanych dla innych, odrębnych gałęzi nauki. Przykładem dobrym i aktualnym pod względem bieżącego zainteresowania ośrodków akademickich mogą służyć modele agentowe wywodzące się z idei pierwotnie związanych z cybernetyką, a znajdujące zastosowanie w ekonomii, biologii, medycynie, socjologii i wielu innych dziedzinach. Pomiędzy przedmiotami i metodami badań nad złożonością rysuje się wobec tego relacja przypominająca związek wiele-do-wielu, w której systemy złożone i metody użyte do ich opisu występują w rozmaitych, różnie dobranych konfiguracjach.

Złożoność zdaje się zatem cechą uniwersalną i jednorodną, posiadającą to samo znaczenie i wywodzącą się $\mathrm{z}$ tych samych źródeł bez względu na rodzaj i naturę zjawiska, w którym się przejawia. Występowanie różnych typów i odmian złożoności może być swoistym wrażeniem wynikającym z konieczności zawężenia kontekstu jej obserwacji i analizy do obszaru odpowiadającego jednej, wybranej dyscyplinie, którą reprezentuje badacz posługujący się charakterystyczną metodologią badań i wyznaczający sobie ściśle określone cele poznawcze. Rozwiązując problemy logistyczne w systemie ekonomicznym tworzonym przez ludzkie społeczeństwo, dostrzega się złożoność algorytmiczną; badając sieci relacji międzyludzkich, napotyka się złożoność strukturalną czy fraktalną; obserwując zachowania organizacji czy opracowując metody zarządzania nimi, dotyka się złożoności behawioralnej, organizacyjnej, komórkowej. W każdym przypadku dotyka się tylko fragmentu większej całości, jaką stanowi złożoność rozumiana jako pewna uniwersalna własność natury. $Z$ tego względu przytoczone wcześniej próby usystematyzowania form złożoności, jak na przykład typologia opisana 
w pracy C. Mesjasza [2010], nie prowadzą do wydzielenia rozłącznych klas, lecz raczej zazębiających się obszarów, a ponadto te systematyki same nakładają się oraz wzajemnie uzupełniają.

Nie jest to sytuacja zarezerwowana jedynie dla nauk zajmujących się systemami społecznymi i ekonomicznymi. Podobne wrażenie odmienności zjawisk posiadających w rzeczywistości wspólną naturę można spotkać także w naukach przyrodniczych i technicznych, ograniczających perspektywę obserwacji zjawisk do wybranego wąskiego zakresu i skupiających się na manifestacjach pierwotnych fenomenów, które są na tyle odległe od ich podstawowych mechanizmów, że wytwarzają złudzenie całkowitej odrębności. Przykładem mogą być oddziaływania elektromagnetyczne obecnie uznawane za jedną z czterech podstawowych, uniwersalnych sił przyrody i decydujące o przebiegu zjawisk, które przez wiele stuleci w ogóle nie były traktowane jako spokrewnione ze sobą. Reakcje chemiczne zachodzące podczas spalania drewna czy wzrostu roślin, działanie przekładni pasowej czy elektrycznej żarówki, postrzeganie barwy, dźwięku bądź dotyku ludzkimi zmysłami albo praca komputera generującego wirtualne krajobrazy - to wszystko przejawy tego samego oddziaływania, niedającego się ograniczyć tylko do tradycyjnie pojmowanego magnetyzmu i elektryczności, których wydzielanie $\mathrm{z}$ bogactwa procesów otaczających człowieka w jego środowisku jest sztucznym zabiegiem i nie odpowiada rzeczywistości.

Podążając dalej tym tokiem rozumowania, można przyjąć pogląd, według którego wyodrębnianie systemów złożonych spośród mnogości różnorodnych systemów będących przedmiotem obserwacji człowieka nie odpowiada w pełni naturalnemu porządkowi rzeczy. Złożoność nie stanowi cechy obecnej lub nieobecnej w rozważanych układach, lecz przeciwnie, jest cechą pierwotną, wszechobecną w całej przyrodzie i uniwersalną zarówno w odniesieniu do systemów naturalnych, jak i tych stworzonych sztucznie przez człowieka. Tak rozumiana złożoność może w niektórych systemach ujawniać się w postaci skomplikowanych zachowań bądź struktur, w innych zaś pozostawać niedostrzegalna do czasu zaistnienia okoliczności, które pozwolą ją uwydatnić. Nawet gdy złożoność nie manifestuje się w sposób jawny, wciąż pozostaje obecna w systemie, tak jak oddziaływania fizyczne, które nie zawsze muszą być obserwowalne, choć są stale obecne. Aby przekonać się na przykład o złożoności przestrzennej struktury wody, trzeba ją najpierw zamrozić do postaci płatków śniegu - lecz samo oziębienie nie wnosi nic nowego do właściwości, a jedynie stwarza okazję do ujawnienia się złożoności. Podobnie, aby zaobserwować skomplikowane zachowania tłumu ludzi, trzeba najpierw zebrać odpowiednią liczbę osób, choć samo ich zgromadzenie nie powoduje zmian charakterów i osobowości, lecz tylko pozwala zaobserwować niektóre zachowania na co dzień niedostrzegalne. 
Przyjmując, że złożoność tkwi w samej naturze i nie jest konsekwencją pewnych cech posiadanych przez systemy, lecz raczej podłożem, na którym te specyficzne cechy mogą się ujawniać, można zauważyć, że badanie złożoności prowadzi do odsłonięcia istotnych właściwości całej przyrody, a nie tylko wybranych jego fragmentów. Oznacza to, że prace zmierzające do poznania złożonych układów fizycznych, biologicznych czy chemicznych pozwalają w jakimś stopniu również lepiej zrozumieć zachowania systemów ekonomicznych i ludzkich organizacji. Podobna relacja zachodzić będzie także w kierunku przeciwnym: dokonania nauk ekonomicznych w zakresie wyjaśniania skomplikowanych zjawisk i zachowań obserwowanych w gospodarce i funkcjonowaniu organizacji będą wzbogacać także inne dziedziny nauki i dostarczać im nowych koncepcji pomocnych w badaniu złożoności systemów o pozaekonomicznym charakterze.

Przeniesienie złożoności niejako poza system, w stronę natury, w której pozostaje on zanurzony, powoduje, że można zadać ponownie pytanie o znaczenie pojęcia systemu złożonego. Rozmaite przytoczone wcześniej spojrzenia na złożoność systemów ekonomicznych i społecznych dotyczyły pewnych własności przypisanych samemu rozważanemu systemowi. Jednak skoro system nie wytwarza złożoności sam w sobie, lecz dziedziczy ją ze swojego podłoża, stając się jedynie środowiskiem odpowiednim do tego, by tę podstawową złożoność można było zaobserwować w jej zachowaniu bądź strukturze, to czy wobec tego określenie „złożony” używane w stosunku do systemu trafnie oddaje taką sytuację? Jeżeli złożoność nie jest atrybutem konkretnego systemu, lecz bardziej uniwersalną własnością przyrody, wówczas należałoby używać raczej określenia system, w którym ujawnia się złożoność - dosyć niewygodnego, choć bliższego prezentowanej tu perspektywie postrzegania złożoności. Sformułowanie system złożony jest bardzo silnie rozpowszechnione i zdecydowanie bardziej poręczne, wobec czego zastępowanie go inną konstrukcją językową nie wydaje się celowe. Przypominałoby to analogiczną próbę zastąpienia w fizyce terminu obwód elektryczny określeniem układ, w którym manifestują się zjawiska elektryczne, mimo że byłoby ono bliższe prawdzie, skoro zjawiska te są wszechobecne w przyrodzie i głęboko wrośnięte w naturę fizykalnego świata. W niniejszych rozważaniach pojęcie systemu złożonego jest więc używane zgodnie z powszechnym zwyczajem, choć zyskuje nową interpretację: jest to system, w którym wszechobecna złożoność przyrody manifestuje się w obserwowalny sposób.

\section{Złożoność organiczna}

Przedstawione stanowisko dotyczące powszechności i uniwersalności tego, co nazywa się złożonością, skłania do poszukiwań pewnego wzorca powtarzalnego 
w szerokim zakresie badanych systemów wykazujących skomplikowane zachowania bądź nietrywialną strukturę. Nie chodzi tu jednak o wzorzec szczególnego zachowania czy struktury, przeciwnie, dotyczyć powinien on raczej takich atrybutów systemu, które obecne są zanim jeszcze będzie obserwowalne złożone zachowanie i zanim system przyjmie złożoną strukturę. Poszukiwać należy więc ogólnego planu powracającego w systemach istniejących spontanicznie i naturalnie, w wielu różnych skalach i w rozmaitych obszarach przyrody, a także kultury i cywilizacji człowieka.

Systemy złożone spotykane w różnorodnych kontekstach nie mają charakteru monolitycznego, przeciwnie, zbudowane są z wielu elementów. Systemy gospodarcze państw składają się z licznych organizacji, społeczności tworzone są przez wiele osób, podobnie jak ławice ryb czy kolonie mrówek złożone są z tysięcy osobników. Każdy rozbudowany organizm, w tym również człowiek, składa się z wielu komórek, a każda z nich z kolei z licznych makromolekuł - te hierarchiczne podziały można kontynuować, dochodząc do cząstek elementarnych, na których poziomie obecnie rozciąga się granica tego, co współczesna fizyka uważa za niepodzielne. Jeżeli przyjąć, że złożoność jest wszechobecna w naturze, to potencjał wytwarzania owej złożoności musi być zawarty już w elementarnych składnikach całości systemu.

Można zatem konsekwentnie zadawać pytanie o źródło tego potencjału. Jakie własności obiektów powodują, że w ich zbiorowości może ujawniać się bogactwo złożonych zachowań, niekiedy na bardzo odległych piętrach hierarchicznej organizacji? Które atrybuty ludzkiego umysłu stwarzają podłoże dla chaotycznych wahań notowań giełdowych lub samopodobnej struktury wielkomiejskich aglomeracji? Jakie własności komórek nerwowych pozwalają sprawnie zarządzać organizacjami, rozwiązywać problemy optymalizacyjne, uczyć się i adaptować do zmiennych warunków? Jakie cechy atomu węgla sprawiają, że życie biologiczne oparte na związkach tego pierwiastka może przejawiać skomplikowane, społeczne formy? Kwestie te, choć mogą wydawać się aż nazbyt fundamentalne, nie mają jednak zmierzać do poznania, jaki jest dokładny mechanizm odpowiedzialny za takie właśnie zachowania realnych systemów. Ich celem jest ustalenie, które spośród właściwości elementów składowych systemu są niezbędne, by móc spodziewać się ujawnienia złożoności, niezależnie od jej faktycznej postaci, a także po usunięciu których system przestanie być złożony.

Jako odpowiedź na powyższe pytania można wprowadzić pojęcie złożoności organicznej charakteryzującej się następującymi cechami: asymetrią elementów, mnogością elementów, istnieniem oddziaływań pomiędzy elementami. W systemach posiadających wszystkie te trzy cechy będą istnieć warunki do ujawnienia się złożoności nie wskutek narzuconego im z zewnątrz zachowania bądź wymuszonej struktury, lecz dzięki samym tym wrodzonym własnościom. Obecność 
różnorodnych symetrii oraz ich specyficznych naruszeń warunkuje istnienie obiektów przyjmujących odróżnialne od siebie stany, wielość tych obiektów dostarcza kombinatorycznego podłoża, na którym z kolei oddziaływania między elementami mogą dynamicznie kształtować rozbudowane struktury. W ten sposób złożoność wywodząca się z wymienionych trzech własności systemów jest $\mathrm{w}$ istocie bardzo naturalna $\mathrm{w}$ sensie bliskości fundamentalnym własnościom rzeczywistych systemów obserwowanych w przyrodzie.

Warto także rozważyć znaczenie proponowanej tu nazwy złożoności organicznej. Przymiotnik organiczny użyty jest $\mathrm{w}$ tej frazie $\mathrm{w}$ znaczeniu podkreślającym ścisły, fundamentalny, naturalny i nierozerwalny związek tej złożoności z systemem, który ją prezentuje. Organiczny znaczy więc wrośnięty, przyrodzony, stanowiący spójną całość. Jest to użycie podobne do takich sformułowań, jak wojskowa jednostka organiczna (jednostka stanowiąca permanentną część składową większej jednostki), prawo organiczne (zbiór aktów prawnych konstytuujących podstawy funkcjonowania rządu lub organizacji) czy organiczne wyszukiwanie (w wyszukiwarce internetowej rezultaty przeszukiwania autentycznych zasobów sieciowych, a nie płatnych ogłoszeń). Słowo to nie musi oznaczać więc żadnego związku ze złożonością obserwowaną wśród organizmów żywych, choć etymologiczne powiązania sprawiają, że przenoszenie cech organizmu na złożone organizacje jest częstą metaforą spotykaną w koncepcjach systemów ekonomicznych [Morgan 2008], której przykłady można znaleźć w polskiej tradycji już w pracach K. Adamieckiego [Czech 2007]. Nawiązując do konotacji biologicznych, całkowicie skądinąd uzasadnionych, można przenośnie stwierdzić, że ten rodzaj złożoności jest wrośnięty w system i nie daje się z niego usunąć poprzez rozszczepienie na pojedyncze elementy, z których każdy jest w stanie dać początek nowej złożoności, jeśli tylko zostanie dostatecznie zwielokrotniony. Zamieniając porządek wyrazów, można określić taki system jako organicznie złożony.

Wymienione własności asymetrii, liczności i obecności oddziaływań nie tylko dają się odszukać w systemach ekonomicznych i społecznych, ale mają również dużo bardziej uniwersalny charakter. W odniesieniu do układów socjoekonomicznych cechy te stanowią ekonofizyczne metafory, które pozostają w ścisłym związku z równoległymi koncepcjami rozważanymi we współczesnej fizyce i wyrastającymi z potrzeby wyjaśnienia istotnych kwestii dotyczących natury fizykalnej rzeczywistości. Przyroda, będąc źródłem wszechobecnej złożoności, a jednocześnie stanowiąc realne środowisko działania człowieka i jego wytworów, może dostarczać inspiracji przy budowaniu modeli zjawisk i procesów ekonomicznych, które tylko pozornie są odległe od obszaru badań nauk przyrodniczych. Nie jest przypadkiem więc, że cechy systemów organicznie złożonych mają także swoje fizyczne interpretacje. 
Asymetria elementów systemu wprowadza zdolność przyjmowania przez nie rozróżnialnych stanów. Można interpretować ją czysto geometrycznie jako brak symetrii pozwalający odróżnić poszczególne orientacje obiektów w przestrzeni, zmiany ich położenia i obroty. Tego rodzaju asymetrię posiadają na przykład figury składające się na nieperiodyczne parkietaże, których wzory nigdy nie ulegają powtórzeniu. Jednak w stosunku do systemów ekonomicznych, wykazujących dynamiczny charakter, bardziej odpowiednia jest inna interpretacja asymetrii jako obecności pewnej liczby zmiennych stanu, które są eksponowane na zewnątrz elementów i pozwalają odróżniać je od siebie, a także obserwować zachodzące zmiany. Dzięki złamaniu symetrii możliwe staje się rozróżnianie tożsamości obiektów, przez co system staje się wewnętrznie różnorodny, złożony, a elementy mogą zachowywać się indywidualnie, niezależnie oraz dają się zestawiać w struktury o odmiennych konfiguracjach. Należy pamiętać, że system składa się z wielu elementów, więc nawet jeśli asymetria pojedynczego obiektu jest znikoma i ogranicza się tylko do jednej binarnej zmiennej stanu, to w miarę przybywania ich ilości liczba możliwych stanów całego systemu rośnie wykładniczo.

Można zauważyć, że pojęcie asymetrii znajduje też swoją bardziej humanistyczną interpretację w nowoczesnych koncepcjach zarządzania organizacjami inteligentnymi. Różnorodność i odmienność ludzi pod względem kulturowym w tym kontekście staje się pożądaną cechą [Stańczyk 2007]. Podobnie różnice w poglądach, doświadczeniach, kompetencjach i wyrobionych sposobach rozwiązywania problemów przez pracowników są cennym kapitałem przedsiębiorstwa [Borowska 2008]. Różnorodność agentów ekonomicznych odgrywa również kluczową rolę w ewolucyjnej dynamice organizacji [Cohendet i Llerena 1998]. Brak asymetrii, a więc pełna symetria elementów systemu powoduje, że obiekt zachowuje niezmienność pomimo zmian zachodzących w systemie - tak jak doskonała sfera pozostaje w tym samym stanie bez względu na próby jej obracania. Geometrycznym przykładem może służyć fraktalny trójkąt Sierpińskiego, który tylko pozornie jest złożony, w rzeczywistości zaś jest nieskończenie monotonny, do jego opisania wystarcza bardzo niewiele informacji, a w jego strukturze panuje wciąż powracająca symetria. Bardziej ekonomiczną ilustracją mogłoby być hipotetyczne społeczeństwo złożone z klonów tej samej osoby: gdyby wszyscy ludzie zachowywali się w pełni symetrycznie, nie mógłby istnieć handel, wykluczona byłaby konkurencja i nie powstawałyby żadne organizacje posiadające struktury zarządcze.

Mnogość elementów jest konieczna, by ich asymetria mogła ujawnić się w różnorodności konfiguracji. Duża liczba obiektów pomnaża liczbę zmiennych stanu systemu i otwiera drogę do złożoności o charakterze kombinatorycznym. Wiele rozróżnialnych elementów może tworzyć przestrzenne układy, zajmując określone położenia, dzięki czemu system zyskuje wewnętrzną organizację, 
której interpretacja zależy od przyjętego w danym modelu rozumienia pojęcia przestrzeni. Im więcej system zawiera elementów, tym większa jest jego potencjalna złożoność i tym więcej informacji może być konieczne do pełnego opisania jego stanu jednak pod warunkiem, że asymetria wzbogaca mnogość składników o możliwość rozróżnienia poszczególnych ich konformacji [Lin 2008]. Sama liczebność elementów bez naruszonej symetrii nie zapewnia jeszcze tego poziomu złożoności: miliard symetrycznych atomów obojętnego gazu utworzy jedynie bezkształtną chmurę, podczas gdy zaledwie kilka tysięcy atomów zdolnych do wytwarzania zorientowanych przestrzennie wiązań może zbudować cząsteczkę białka o zaskakująco skomplikowanej architekturze.

Wprawdzie niektóre zjawiska wykazują złożoność już przy niewielkiej liczbie elementów tworzących układ, jak na przykład wspomniany problem trzech ciał, jednak w wielu spotykanych na co dzień systemach zbyt mała liczebność elementów może stłumić złożoność. Wyraźnie jest to widoczne w przypadku zagadnień o charakterze optymalizacyjnym, takich jak często spotykany w zagadnieniach ekonomicznych problem komiwojażera. Należy on do problemów NP-trudnych i jego dokładne rozwiązanie wymaga nakładów pracy rosnących wykładniczo wraz z liczbą miast. Jednak problemy NP-trudne dla niewielkich zbiorów danych wydają się bardzo proste, człowiek może bez większego trudu rozwiązać ręcznie problem komiwojażera dla kilku miast. Nawet jeżeli elementy systemu same w sobie wykazują skomplikowaną dynamikę, to przy zbyt małej ich liczbie nie wzniosą się na wyższy poziom złożoności. Choć samotny Robinson Crusoe jest w stanie ucywilizować bezludną wyspę, to mimo wszystko nie zdoła zbudować na niej złożonego społeczeństwa posiadającego w pełni rozwiniętej gospodarki czy administracji publicznej.

Oddziaływania pomiędzy elementami systemu są wreszcie trzecim komponentem odpowiedzialnym za wystąpienie złożoności. Oddziaływania te muszą być integralną częścią systemu, dzięki której obiekty zmieniają swoje stany bez potrzeby ingerencji zewnętrznego czynnika pochodzącego spoza systemu. Dobrym przykładem w fizyce może być grawitacja napędzająca ruch obiektów astronomicznych, zaś w społeczeństwie ludzi - obecność relacji międzyludzkich, skłaniających do nawiązywania znajomości, rozwijania kooperacji bądź konkurencji czy tworzenia grup i lokalnych społeczności. Dzięki oddziaływaniom system otrzymuje wewnętrzny napęd, stając się systemem dynamicznym. Interakcje między elementami pozwalają ujawnić się niesymetriom, prowadząc do wytworzenia nietrywialnych struktur, przez co system w pewnym sensie samorzutnie eksploruje ukryte w nim zasoby złożoności [Axelrod i Cohen 2001].

Brak oddziaływań powoduje, że poszczególne elementy są od siebie odizolowane w kontekście systemu i dopiero siły spoza niego będą mogły nadać systemowi określoną konfigurację. Nie jest to wówczas system złożony sam w sobie, 
lecz jedynie podlegający wpływowi innego systemu złożonego. Przypomina to armię figur szachowych niezdolnych do wykonania samodzielnego ruchu, która swój złożony układ na szachownicy zawdzięcza jedynie wyrafinowanej strategii zrodzonej w umyśle gracza. Podobnie będzie zachowywać się personel obsługujący skomplikowany proces produkcyjny w przedsiębiorstwie: pracownicy mogą wykonywać złożone czynności zgodnie z wyuczonym planem, ale nie będą zdolni samodzielnie stworzyć takiego procesu od podstaw, jeśli nie będą odczuwali zależności i powiązań pomiędzy pełnionymi rolami.

Oddziaływania nie muszą jednak być rozumiane dosłownie jako siły, które poruszają obiekty. Warto pamiętać, że obecność oddziaływań oznacza także obecność pewnej formy energii, to zaś wprowadza w systemie możliwość rozróżniania stanów mniej lub bardziej korzystnych energetycznie. Zakorzeniona w całej naturze dążność do minimalizacji energii zgromadzonej w systemach nie tylko napędza ich dynamikę, ale także stanowi kryterium porównywania układów prostych i złożonych nawet wówczas, gdy pozostają statyczne. Przykładem takiej energetycznej interpretacji oddziaływań może ponownie być problem komiwojażera: koszt podróży między miastami stanowi analogię energii oddziaływania pomiędzy nimi, a sama natura problemu optymalizacyjnego polega na minimalizacji łącznej energii cyklu hamiltonowskiego w grafie zupełnym. Usunięcie oddziaływań z takiego układu, a więc brak kosztów podróży powoduje, że trasy przestają być odróżnialne pod względem energetycznym - problem wyboru optimum przestaje więc istnieć.

\section{Podsumowanie}

Przedstawiona koncepcja złożoności organicznej stanowi oryginalne, całościowe ujęcie złożoności systemów społeczno-ekonomicznych, nieograniczające się jednak tylko do tego rodzaju zbiorowości. Układy elementów asymetrycznych, zwielokrotnionych i powiązanych oddziaływaniami występują również w wielu innych dziedzinach nauki zajmujących się systemami złożonymi. W podejściu organicznym kładzie się nacisk na te atrybuty systemów, które sprawiają, że naturalna złożoność jest na stałe wpisana w ich charakterystykę: oczekiwanie asymetrii, mnogości i interaktywności wynika z przyjęcia założenia o uniwersalnej naturze złożoności, według którego potencjał wytwarzania skomplikowanych form i zachowań nie tyle leży w specyficznej konstrukcji systemu, co przenika elementarne własności jego składników.

Wyróżnienie cech składających się na złożoność organiczną ma nie tylko wartość poznawczą, ale jest również istotne z perspektywy tworzenia modeli systemów złożonych, takich jak systemy ekonomiczne i społeczne. Konstruując 
modele odzwierciedlające rzeczywistą budowę systemów złożonych, należałoby wyposażyć ich elementy w analogiczne cechy zapewniające konieczną zdolność wytwarzania złożoności. Modele posiadające postulowane atrybuty, a więc obejmujące liczne i rozróżnialne elementy oraz uwzględniające interakcje między nimi, będą dobrze odtwarzać naturalne cechy tych systemów, stanowiąc dogodne narzędzie ich badania. $\mathrm{Z}$ drugiej strony pozbawienie modelu systemu jednego z tych atrybutów odbierze mu możliwość prezentowania złożonej struktury bądź zachowań. Wydaje się więc wskazane, by w metodach badania systemów ekonomicznych i społecznych uwzględniać cechy złożoności organicznej już na etapie tworzenia modeli i prowadzenia symulacji.

\section{Literatura}

Arora S., Barak B. [2009], Complexity Theory: A Modern Approach, Cambridge University Press, Cambridge.

Arthur W.B. [1999], Complexity and the Economy, ,Science”, vol. 284, nr 5111.

Axelrod R., Cohen M.D. [2001], Harnessing Complexity: Organizational Implications of a Scientific Frontier, Simon \& Schuster, New York.

Borowska A. [2008], Zarzadzanie różnorodnością, Zeszyty Naukowe Politechniki Białostockiej. Ekonomia i Zarządzanie, nr 12.

Castellani B., Hafferty F.W. [2009], Sociology and Complexity Science. A New Field of Inquiry, Springer, Berlin.

Challet D., Zhang Y.C. [1997], Emergence of Cooperation and Organization in an Evolutionary Game, „Physica A: Statistical and Theoretical Physics”, vol. 246, nr 3-4.

Cohendet P., Llerena P. [1998], Theory of the Firm in an Evolutionary Perspective: A Critical Development, „Competence, Governance and Entrepreneurship”, Druid, Copenhagen.

Czech A. [2007], Adamieckiego metafory organizacji, „Współczesne Zarządzanie”, nr 2.

Diacu F. [1996], The Solution of the n-body Problem, „The Mathematical Intelligence”, vol. 18.

Lin S.K. [2008], Gibbs Paradox and the Concepts of Information, Symmetry, Similarity and Their Relationship, „Entropy”, vol. 10, nr 1.

Lorenz E. [1963], Deterministic Nonperiodic Flow, „Journal of Atmospheric Sciences”, vol. 20.

Mesjasz C. [2009], Interpretations of Complexity of Social Systems [w:] Proceedings of the 4th Polish Symposium on Econo- and Sociophysics, eds. S. Drożdż et al., Polish Academy of Sciences, Warsaw.

Mesjasz C. [2010], Complexity of Social Systems, „Acta Physica Polonica A”, vol. 114, $\mathrm{nr} 4$.

Morgan G. [2008], Obrazy organizacji, Wydawnictwo Naukowe PWN, Warszawa.

Modeling Complexity in Economic and Social Systems [2002], red. F. Schweitzer, World Scientific, New Jersey. 
Pawełek B. [2008], Metody normalizacji zmiennych $w$ badaniach porównawczych złożonych zjawisk ekonomicznych, Wydawnictwo Uniwersytetu Ekonomicznego w Krakowie, Kraków.

Pociecha J., Pawełek B. [2010], Bankruptcy Prediction and Business Cycle [w:] Contemporary Problems of Transformation Process in the Central and East European Countries: Proceedings of 17th Ukrainian-Polish-Slovak Scientific Seminar, ed. N. Vasilivna Kovalik, The Lviv Academy of Commerce, Lviv.

Prigogine I. [1961], Introduction to Thermodynamics of Irreversible Processes, Interscience, New York.

Scheinkman J.A., Woodford M. [1994], Self-Organized Criticality and Economic Fluctuations, ,The American Economic Review”, vol. 84, nr 2.

Stańczyk S. [2007], Umiejętność zarządzania różnorodnością kulturowa-odniesienia teoretyczno-praktyczne, Prace Naukowe Akademii Ekonomicznej we Wrocławiu Zarządzanie, nr 5(1187).

Waldrop M.M. [1992], Complexity: The Emerging Science at the Edge of Order and Chaos, Simon \& Schuster, New York.

\section{Organic Complexity as a New Approach to the Complexity of Economic Systems}

Economic and social systems belong to a wide class of complex systems, the subject of research in many areas of science. There are many approaches to the complexity of such systems, which differ in how they define and explain the sources of complex behaviour. As complexity is widespread in nature, it seems legitimate to seek a universal pattern repeated in all kinds of complex systems. This article presents a new concept of organic complexity, understood as a set of three attributes: asymmetry, multiplicity and interactivity of a system's components. Systems with these characteristics will have the ability to develop complex structures or behaviours. The organic complexity approach can be useful in building models of complex economic and social systems.

Keywords: complex systems, agent-based model, symmetry, self-similarity. 